\title{
Review
}

\section{Pancreatic Beta-cell growth and diabetes mellitus}

\author{
I.Swenne \\ Departments of Paediatrics and Medical Cell Biology, Uppsala University, Uppsala, Sweden
}

Glucose homeostasis is tightly controlled by, first and foremost, insulin. There is a minute-to-minute regulation of insulin output from the Beta cell to meet changing demands at and between meals. There is also a long-term adaptation of insulin production by changes in total Betacell mass. Diabetes mellitus develops if any one of these processes is insufficient and causes absolute or relative insulin deficiency. The regulation of insulin biosynthesis and release in relation to the aetiology of diabetes has been intensely studied, while the role of Beta-cell growth has met with less interest until recent years.

In Type 1 (insulin-dependent) diabetes there is a loss of Beta cells and decompensation of metabolism following autoimmune aggression [1]. Insulin production often reccurs shortly after onset of clinical disease ("honeymoon period") suggesting an effort by the reduced Beta-cell mass to meet insulin demands. In Type 2 (non-insulin-dependent) diabetes pathogenesis is less clear and probably multifactorial but there is evidence to suggest that a reduced insulin secretory response to glucose and a limited capacity for Beta-cell replication predisposes to the disease $[2,3]$. Studies of the regulation and limitations of Beta-cell growth thus appear appropriate for the understanding of the aetiology and pathogenesis of diabetes. Present knowledge on the regulation of Beta-cell growth, with emphasis on recent studies of Beta-cell DNA replication in vitro, is reviewed in this paper.

\section{Growth of the Beta-cell mass: measurements of neogenesis, hypertrophy and replication}

In early studies changes in total Beta-cell or islet mass was estimated by volumetric methods. Beta-cell growth would then include three aspects: neogenesis or differentiation of Beta cells from precursors, change in the size of individual Beta cells and Beta-cell replication.

Early observations of pancreatic cells with both endocrine and non-endocrine characteristics, of insulin-positive cells in ductular epithelium and growth of islets in association with ducts were taken as evidence of islet cell neogenesis. However, in the absence of morphological markers for Beta-cell precursors, direct measurements of Beta-cell neogenesis are not possible. There is, however, circumstantial evidence to indicate the existence of the process since in fetal rats there is an increase of Beta-cell mass at the end of gestation which cannot be explained by replication and hypertrophy only $[4,5]$.

Growth in size of individual Beta cells has been little studied but appears to be regulated by nutritional stimuli. Glucose stimulation increases Beta-cell size and is accompanied by ultrastructural signs of increased insulin production [6]. Hypertrophy would thus represent an adaptation to increased demands on insulin production but it is evident that there are limitations to this aspect of Beta-cell growth.

Islet cell replication has usually been estimated by incorporation of tritiated thymidine and the method has been extensively validated [7]. More recently the use of bromodeoxyuridine as thymidine analogue and its subsequent detection with antibodies has come into use [8]. Biochemical estimations of islet thymidine kinase, an enzyme expressed only in the $S$ phase of the cell cycle, can also be used as an index of proliferation (Fig. 1) [9]. These new methods yield results similar to those of thymidine incorporation but have technical advantages which may make them preferable.

\section{Nutrient regulation of Beta-cell replication}

Glucose-stimulated DNA replication is a well-documented characteristic of the Beta cell [10]. In view of this unique feature it is surprising that in many investigations the preparations of islets or Beta cells used are not tested for glucose-stimulated DNA replication prior to applying other potential growth factors. By the same token, measurements of insulin production in parallel with those of cell replication would further affirm the quality of the preparation.

Besides D-glucose, D-mannose or a mixture of essential amino acids, which are metabolized by the Beta cell, 


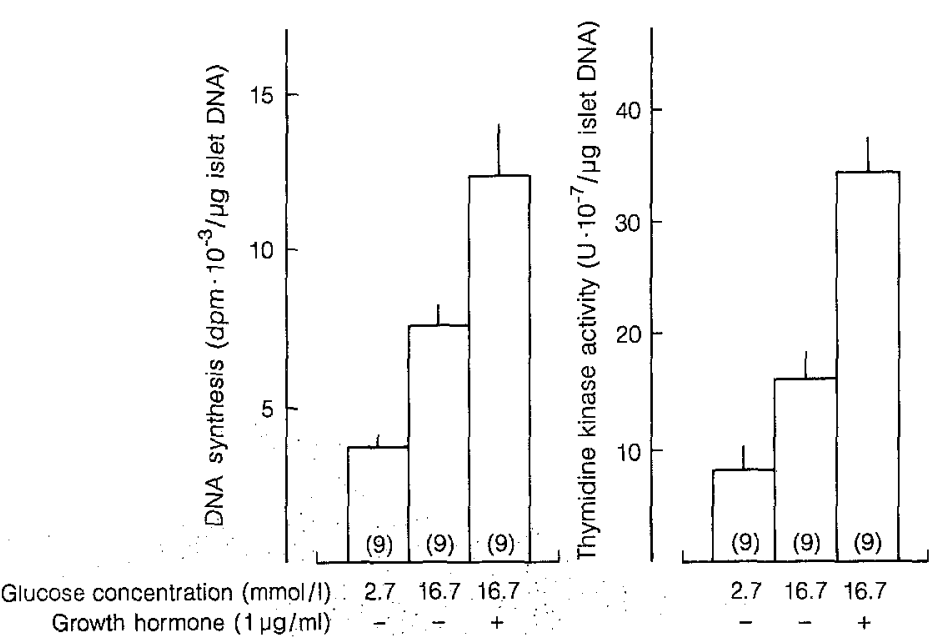

Fig. 1. DNA replication in rat islets cultured under different stimulatory conditions. Replication was monitored as incorporation of tritiated thymidine (left) or as thymidine kinase activity (right). [9]

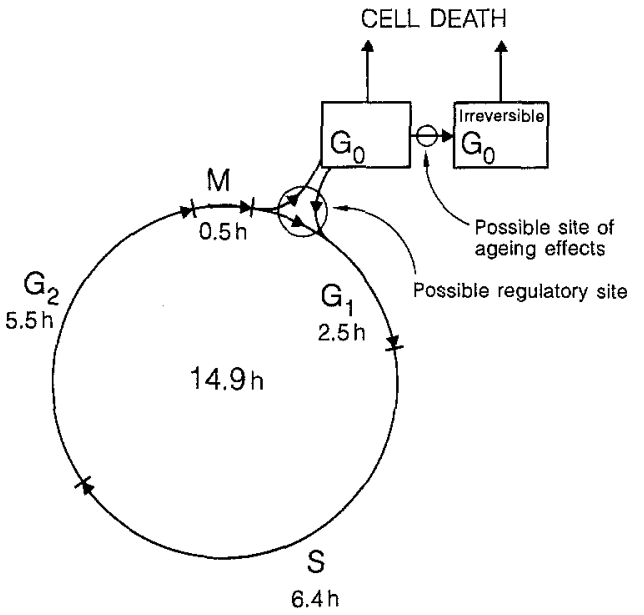

Fig. 2. The cell cycle of cultured rat pancreatic islet cells and its subdivision into phases. Note the putative sites for regulation of entry into active cell cycle and for effects of ageing. [14-16]

stimulate replication $[11,12]$ whereas inhibition of glucose metabolism with mannoheptulose abolishes the stimulatory effects [13]. Unmetabolizable sugars such as L-glucose, 3-0-methylglucose or fructose are unable to stimulate replication [11]. These investigations indicate that Beta-cell replication, in parallel with insulin biosynthesis and release, is linked to the metabolism of regulatory substrates.

Further information on the regulation of Beta-cell replication has been obtained by analysis of the cell cycle of proliferating Beta-cells (Fig.2). The duration of the cell cycle and its subdivision into phases is independent of glucose which suggests that glucose regulates the fraction of cells recruited into a 'proliferative compartment' (PC) of cells progressing through the cell cycle [14]. This interpretation of the cell cycle analysis is in agreement with the general concept of a regulatory mechanism at entry into the cell cycle which subsequently proceeds according to a set programme independent of the initial stimulus [15]. Cell cycle analysis under different stimulatory conditions makes it possible to estimate the maximal size of the PC which in fetal rat islets is approximately $10 \%$. The remaining islet cell population would be in an irreversible $\mathrm{G}_{0}$ phase, unable to re-enter the cell cycle [16]. The important issue emerging from these studies is that the regenerative capacity of the islets would depend not only on the stimulus for replication but also on the size of the fraction of cells able to replicate.

\section{Developmental aspects}

The effect on replication of different metabolic substrates varies throughout development. In fetal rat islets, up to day 20 of gestation, glucose does not stimulate replication whereas a mixture of essential amino acids does. At the end of gestation islet cell replication becomes glucose sensitive and the effect of amino acids less prominent (Fig. 3) [17]. Postnatally the fraction of islet cells which can be recruited into the $\mathrm{PC}$ diminishes from $10 \%$ perinatally to less than $3 \%$ in young adults (Fig. 4 ) $[16,18]$. The replicatory response to amino acids is retained into adult life but is less prominent than during fetal life [19].

In view of the perinatal changes of substrates available to the growing organism it seems appropriate with a change from amino acid to glucose regulated islet cell replication in late gestation as a preparation for postnatal life. The factor(s) regulating this developmental switch are unknown. Thyroid hormones and growth hormone have been implicated but found to be without effect on the process [17]. It is noteworthy that glucose stimulation which induces a precocious glucose sensitivity of insulin release $[20,21]$ does not have this effect on islet cell replication.

\section{Genetic aspects}

Pancreatic islets from the two inbred, genetically welldefined, mouse strains $\mathrm{C} 57 \mathrm{~B} 1 / 6 \mathrm{~J}$ and $\mathrm{C} 57 \mathrm{Bl} / \mathrm{Ks} \mathrm{J}$ differ in their capacity for proliferation. In both strains glucose stimulates islet cell replication two-fold but the fraction of cells which can be recruited into the PC is twice as large in the C57B1/6J strain (Fig. 5) [18]. If one of the mutant genes 'diabetes' $(\mathrm{db})$ or 'obese' $(\mathrm{ob})$ is crossed onto these strains different diabetic syndromes develop. In C57B1/6J 


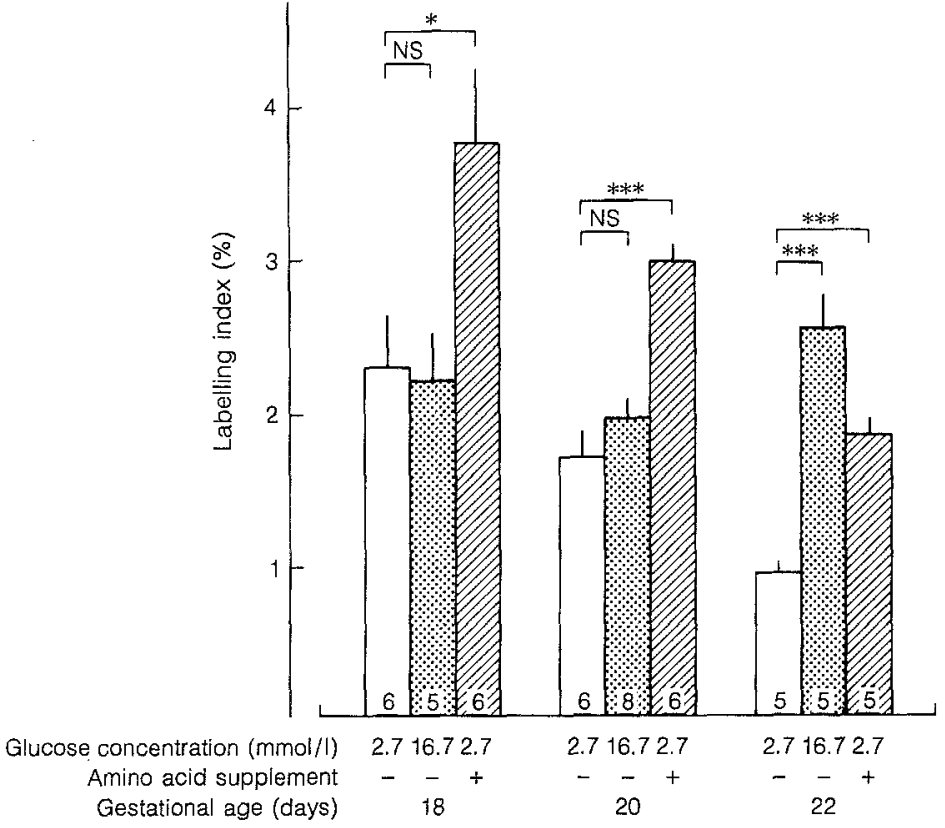

Fig. 3. DNA replication in cultured islets obtained from rat fetuses of different gestational ages. Replication was stimulated by a low glucose concentration (open bars), a high glucose concentration (stippled bars) or a high concentration of essential amino acids (hatched bars). Significance of difference: $* p<0.05, * * * p<0.001$. [17]

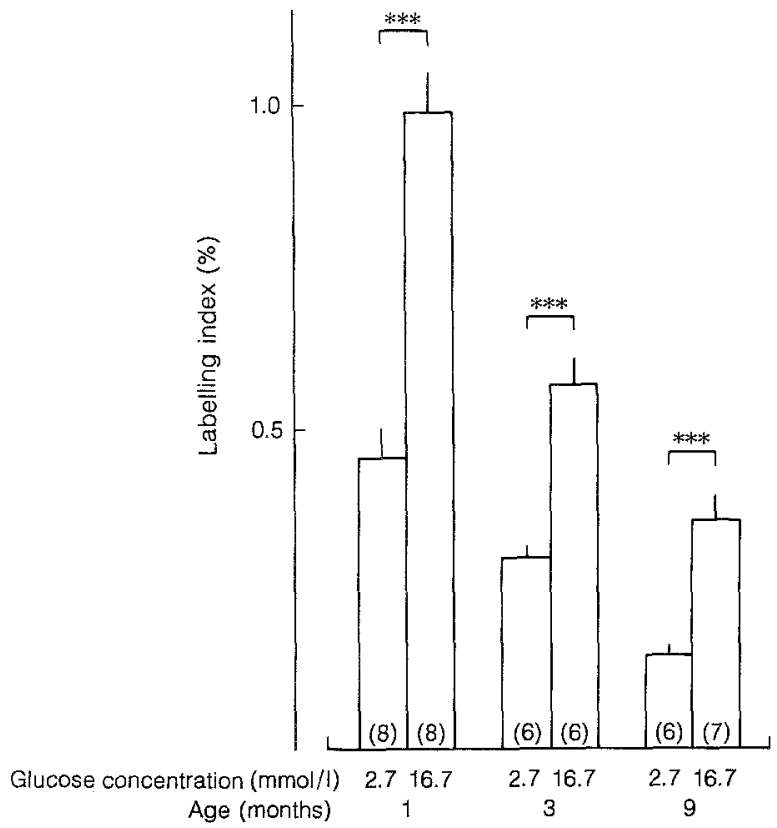

Fig. 4. Glucose-stimulated DNA replication in cultured islets from mice of different ages. Significance of difference: $* * * p<0.001$. [18]

the homozygous carrier of either gene develops mild diabetes, insulin resistance, obesity and extreme islet hyperplasia. In mice of the $\mathrm{C} 57 \mathrm{Bl} / \mathrm{Ks} J$ strain the early course of the syndrome is similar but followed by severe diabetes, weight loss, Beta-cell degeneration and death [22]. These observations suggest a genetically determined capacity for islet cell proliferation which modifies phenotypic expression of diabetic syndromes, a notion in support of the concept of a multifactorial inheritance of human Type 2 diabetes.

Differences in the capacity for islet cell replication between strains have been demonstrated in rats. An association with major histocompatibility haplotypes (MHC) could, however, not be detected [23]. Since certain MHC haplotypes are associated with the development of diabetes in diabetes-prone sublines of the BB/Wistar rat [24] it would appear that the capacity for islet cell proliferation is not a determinant for the development of this autoimmune diabetic syndrome. Indeed, the capacity to expand islet volume upon glucose stimulation is normal in diabetes-prone $\mathrm{BB} /$ Wistar rats prior to onset of disease [25]. The development of diabetes in these rats may therefore be determined predominantly by the progression of autoimmune destruction rather than by the capacity of compensatory processes.

\section{The growth hormone family and insulin-like growth factors}

The stimulatory effects of growth hormone $(\mathrm{GH})$ on insulin production and Beta-cell replication are well-documented [10]. GH belongs to a family of hormones with common ancestral genes and similarities in structure and functional properties [26]. The closely related prolactins and placental lactogens also stimulate islet cell replication [27]. In many tissues GH stimulates the production and release of somatomedins or insulin-like growth factors (IGFs) which in turn stimulate cell proliferation locally, via autocrine or paracrine mechanisms [28]. IGF I and IGF II are released by rat islets [29-31] and exogenously added IGF I or IGF II stimulate islet cell replication [2933], altogether suggesting a regulatory role of IGFs. Insulin, which can interact with the type I IGF receptor [34] also stimulate islet cell replication $[29,33]$. GH, but not glucose or amino acids, stimulates IGF I release from both fetal and adult rat islets concomitant with an increase in islet cell replication $[19,30]$. An antibody against IGF I can partly abolish the GH-stimulated replication [30] (Fig. 6). This indicates a partial mediation by IGF I of the growth promoting effects of GH. By contrast, a similar 


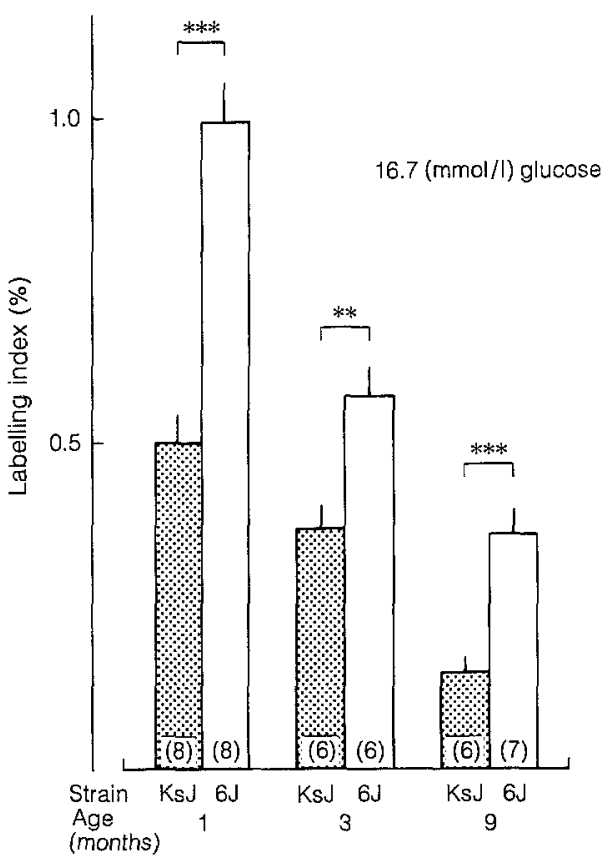

Fig.5. Glucose-stimulated DNA replication in cultured islets from mice of the C57B1/KsJ (stippled bars) and C57B1/6J (open bars) strains. Significance of difference: $* * p<0.01,{ }^{* * *} p<0.001$. [18]

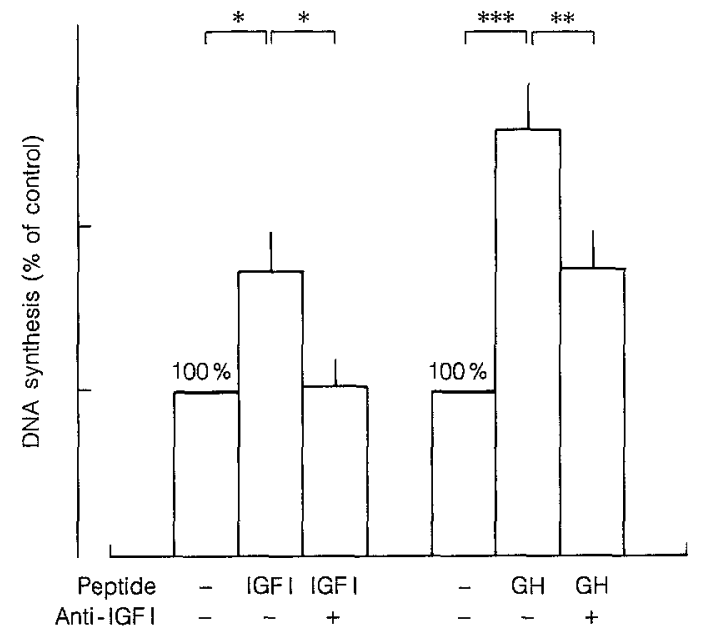

Fig. 6. DNA replication in cultured fetal rat islets after stimulation with somatomedin C/insulin-like growth factor I (IGF I) or growth hormone $(\mathrm{GH})$. Note that an antibody against IGF I abolishes the replicatory response to IGF I but only part of the response to $\mathrm{GH}$. Significance of difference: $* p<0.05,{ }^{* * *} p<0.01$, ${ }^{* * *} p<0.001$. [30]

mediation by IGF I of the stimulation of insulin production cannot be demonstrated $[19,30]$.

In interstitial fluids and plasma IGFs are complexed with IGF binding proteins (IGFBPs) which do not act merely as carriers but also influence the availability and biological actions of IGFs at the tissue level [35]. Indeed, both synergistic and inhibitory interactions with IGFs have been reported $[36,37]$. Fetal rat islets release several molecular species with IGFBP properties of which one, with apparent molecular weight similar to that of IGFBP2 , is stimulated by glucose [31]. Exogenously added IGFBP-2 does not per se affect islet cell replication but acts in synergy with IGF II to enhance the stimulatory ef- fect on replication of the growth factor [31]. It would thus appear that regulation of islet cell replication by $\mathrm{GH}$, IGFs, IGFBPs and nutrients forms a complex network of interactions. It is possible that further studies of the role of IGFBPs in this process may resolve why in some studies the stimulation of islet cell replication by IGFs is poor or absent [38, 39].

There are, however, further issues to be resolved. Many tissues do not express messenger RNAs for IGFs in correlation with the amount of detectable peptide $[40,41]$. Beta cells of rats and humans stain for IGF I [41-43] but are without detectable messenger RNA for IGF I [40, 44] despite evidence of IGF I biosynthesis [45]. It has been suggested that cells which do not synthesize IGFs may be able to sequestrate the peptides and later release them upon stimulation $[41,42]$. This does not rule out regulation of islet cell replication by GH and IGF I as suggested above but the sites of IGF I biosynthesis and storage require further investigation.

Another problem is posed by the similarities between the members of the growth hormone family. Most investigations have been performed with human GH which has considerable lactogenic properties compared to rodent GHs [26]. Rat Beta cells have lactogenic receptors [46] and differences in growth stimulation between rat and human $\mathrm{GH}$, attributed to differences in lactogenic properties, have been demonstrated [47]. The GH effects on islets in vitro are therefore best regarded as demonstrations of possible regulatory pathways [30]. The receptors and members of the growth hormone family operating under physiological conditions remain to be established.

\section{Growth factors, oncogenes and growth-related genes}

In many cell types different polypeptide growth factors, rather than nutrients, regulate replication. Based on experiments with $B A L B / c-3 T 3$ cells platelet-derived growth factor (PDGF) and fibroblast growth factor (FGF) have been termed 'competence factors' since they do not themselves stimulate entry into the cell cycle but render cells able to proliferate upon subsequent stimulation by "progression factors' such as insulin, IGFs or epidermal growth factor (EGF) $[48,49]$. This distinction has not been observed in islets. Both PDGF and IGF stimulate islet cell replication and additive rather than synergistic effects are seen when tested together (Fig. 7) [32]. Islets express only small numbers of PDGF receptors but following transfection with a gene construct coding for the PDGF beta receptor an enhanced response to PDGF can be demonstrated [50]. This indicates that islets possess cellular machinery for growth signal transduction distal to the receptor and suggests that PDGF may have a role in physiological growth regulation. The endocrine islet cells do not themselves produce PDGF-like substances [32] but it is possible that non-endocrine islet cells, i.e. fibroblasts and endothelial cells, synthesize growth factors with local growth-promoting effects. Since PDGF does not stimulate insulin production [32] it would appear that the effects of PDGF involve only the fraction of cells which can be recruited into active cell cycle. 


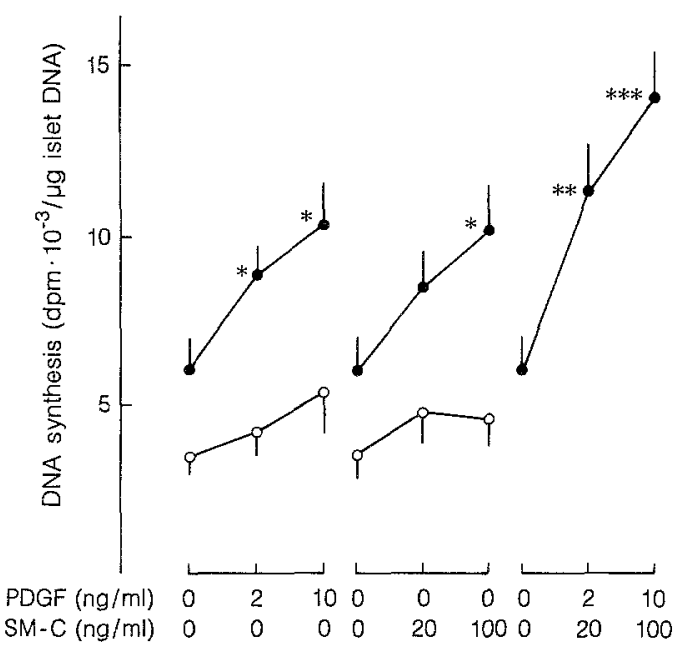

Fig. 7. DNA replication of fetal rat islets cultured with $2.7(\mathrm{O}-\mathrm{O})$ or $16.7(-) \mathrm{mmol} / \mathrm{l}$ glucose and somatomedin C/insulin-like growth factor I (SM-C) and platelet-derived growth factor (PDGF) as indicated. Note that both peptides independently stimulate replication and that effects are additive. Significance of difference vs cultures without hormones: $* p<0.05, * * p<0.01, * * * p<0.001$. [32]

The effect of EGF is unclear since both lack of effect and stimulation of replication and insulin production have been reported [51, 52]. Since islet cells express EGF binding sites [53] an effect of the growth factor would be expected but the significance for islet cell function is unclear.

Viral oncogenes and their normally occurring cellular counterparts the protooncogenes code for proteins which may act as regulators of growth in normal tissues [54]. In normal islets expression of protooncogenes is very low or undetectable [55] but they can be used as tools to study regulation of cell replication. Islets transfected with a gene construct of $\mathrm{v}$-src, which possesses tyrosine kinase activity, have an enhanced cell replication. The stimulation of replication is stronger than that of PDGF + IGF I, which act via receptors with tyrosine kinase activity, suggesting that the v-src transfected cells by-pass normal receptor activation of tyrosine kinase and that the cells are able to respond with replication to increased tyrosine kinase activity [55]. This observation adds further evidence to the existence of growth factor regulated, receptor-mediated islet cell proliferation.

Transfection of cells with a gene construct of c-myc, which codes for a nuclear protein, or with c-Ha-ras, which codes for a GTP-binding protein, does not affect islet cell replication. However, in conjunction these protooncogenes stimulate replication as does carbamylcholine in c-myc transfected cells $[55,56]$. C-Ha-ras and carbamylcholine activate islet phospholipase $\mathrm{C}$ but the role of this process in islet cell replication requires further investigation [56].

Rats subjected to $90 \%$ pancreatectomy develop diabetes within weeks. Treatment with nicotinamide stimulates islet cell regeneration and the incidence of diabetes is lowered. The gene reg (for regenerating gene) has been isolated from islets of such rats [57]. The gene product has been localized to the Beta-cell granules but is not restricted to a proliferating cell fraction [58]. A human reg gene has also been identified and its corresponding protein shown to share homologies with a pancreatic stone protein [59]. Recently a correlation between Betacell replication and reg gene expression in rat islets cultured with different nutrient and hormonal stimulators of replication has been demonstrated [39]. It is, however, not yet clear whether reg gene expression is the cause or consequence of islet cell regeneration. Moreover, the observation that the gene is expressed in all Beta cells may reflect general Beta-cell activation rather than a specific replication-related event which would be expected to involve only a minority of the Beta cells [14].

\section{Gastrointestinal peptides}

Gastrointestinal (GI) peptides modulate the secretion of both digestive enzymes and hormones. Indeed, it appears appropriate that intestinal digestion and metabolic disposal of nutrients share a regulatory pathway, the enteroinsular axis [60]. The classic GI peptides gastrin, cholecystokinin and secretin all stimulate insulin release but among many others gastric inhibitory peptide (GIP) has the strongest insulinotropic action [61]. GIP release is stimulated by carbohydrates and lipids and has been implicated in the aetiology of obesity and hyperinsulinaemia which may precede glucose intolerance and human Type 2 diabetes [60]. Against this background, it is surprising that the effects of GI peptides on islet growth have been little studied. Gastrin and cholecystokinin have been shown to stimulate islet cell replication $[62,63]$ but it is evident that the role of the enteroinsular axis in islet cell growth requires further investigation.

\section{The steroid controversy}

Early work on the effects of steroid hormones on pancreatic islets are unanimous in that glucocorticoid administration in vivo stimulates Beta-cell hypertrophy and proliferation and increases serum insulin concentration [2]. Pancreatic islets have receptors for adrenal steroids [64] and the effects of glucocorticoids observed in vitro are inhibition of insulin release [65] and cell replication [66, 67]. To further investigate steroid effects in vitro Khatim et al. have measured DNA replication as incorporation of radioactive ortho-phosphate into DNA rather than as incorporation of radioactive thymidine $[68,69]$. In such experiments an inhibitory effect of steroid hormones is not observed. Moreover, in islets cultured with steroid hormones the activity of thymidylate synthetase is increased. It is suggested that an increased synthesis of thymidine dilutes the radioactive thymidine pool, decreases its incorporation into DNA and yields an underestimation of DNA replication $[68,69]$. However, ortho-phosphate incorporation into DNA was not validated in glucose-stimulated islets nor was the specific activity of the intracellular thymidine pool directly measured. It is also of interest to note that in islets cultured in the presence of steroid hormones, the thymidine kinase activity is decreased [68] which indicates a diminished DNA replication [9]. 
The difference between the in vivo and in vitro effects makes it difficult to assess the physiological role of glucocorticoids but the weight of evidence favours indirect, stimulatory effects as being predominant in vivo. Glucocorticoids increase hepatic glucose production and peripheral resistance to the actions of insulin. The glycaemic stimulation of the Beta cells may override any direct effect of the steroids but since the compensatory potential of the Beta cells is limited diabetes may develop if the steroid load is excessive. Animals with steroid diabetes have hypertrophied islets $[70,71]$ which suggests that diabetes develops not as a consequence of direct inhibitory effects on Beta-cell function but rather from insufficient compensatory growth and insulin production.

\section{Pregnancy and sex steroids}

During pregnancy the total Beta-cell mass increases $[72,73]$. Islet cell DNA replication is increased but it is possible that the other aspects of growth also contribute to the increased Beta-cell mass [74]. Sex steroids are implicated in the process and pancreatic islets have receptors for both oestrogens [75] and progesterones [76]. Direct effects on islet cell replication have been tested in vitro. Results are, however, confusing since both oestrogens and progesterones have been reported to inhibit or alternatively be without effect on proliferation $[68,69,77,78]$. As with glucocorticoids, the discrepancies between observations in vivo and in vitro are best explained by predominance of indirect effects of the hormones in vivo. In support of this is the observation that increased glucosestimulated insulin release in islets from pregnant rats is partly due to an increased food intake [79], which in turn could be an effect of progesterones. Moreover, peripheral resistance to the actions of insulin is increased during pregnancy [80] and the decreased capacity for glucose disposal would stimulate Beta-cell growth and compensatory increases in insulin production. The regulation during pregnancy of glucose metabolism and Beta-cell growth by sex steroids is thus requiring further investigation and it would appear that such studies are best performed in the intact, pregnant animal.

\section{Cyclic AMP and phosphodiesterase inhibitors}

In Beta cells glucose metabolism increases intracellular cyclic AMP (cAMP) concentrations [81] and a role in glucose-stimulated DNA replication has been suggested. Investigations are contradictory and difficult to interpret. Stimulation of endogenous cAMP formation with forskolin or glucagon enhances islet cell DNA replication $[66,82]$. Cyclic AMP analogues have been reported both inhibitory and stimulatory $[83,84]$. Of phosphodiesterase inhibitors theophylline is inhibitory $[13,83]$ while isobutyl-methyl-xanthine (IBMX) is either stimulatory or inhibitory depending on the concentration used [83, 84]. Theophylline and IBMX have effects on Beta cells, other than phosphodiesterase inhibition, which may influence DNA replication $[85,86]$. This pharmacologic approach may thus be excessive compared to the often subtle changes in cyclic nucleotides observed during the cell cycle [87]. It is also possible that regulation and effects of cAMP are different in proliferating compared to resting Beta cells, but this notion requires further substantiation.

\section{Antidiabetic drugs}

The hypothesis that the antidiabetic effect of sulphonylureas partly depends on stimulation of islet growth is attractive. Early studies of sulphonylurea-treated animals are not in agreement but most suggest hypertrophy and/or neogenesis of islet cells [2]. Investigations in vitro are not conclusive since tolbutamide and glibenclamide have been reported to both stimulate islet cell replication and to be without effect $[66,67,88,89]$. Sulphonylureas stimulate insulin release by interaction with an ATP-dependent potassium channel in the plasma membrane of the Beta cell [90] but whether this can influence replication has not been investigated.

\section{Beta-cell growth and the aetiology of diabetes mellitus}

In obesity total Beta-cell mass is increased in response to increased peripheral insulin resistance. It is conceivable that if the Beta-cell growth response is deficient insulin production may become insufficient and diabetes develop. In strong support of this is the observation of decreased total Beta-cell mass in Type 2 diabetes compared to weight-matched control subjects [3]. It could be argued that a modest decrease of Beta-cell mass cannot cause diabetes in view of the great reserve for insulin production of the islet organ [2]. A reduced Beta-cell mass would, however, be subjected to a persistently increased functional load which in the long-term may exhaust insulin release [91]. Present knowledge therefore suggests that to insulin secretion and insulin resistance, two classic factors investigated for their role in the aetiology of Type 2 diabetes, should be added a third, the capacity for Betacell growth.

A deficient Beta-cell proliferation may be of less importance in the pathogenesis of Type 1 diabetes since the severity of the autoimmune attack may be the most important determinant of outcome. The honeymoon period, with increasing insulin production and decreasing needs for insulin replacement, shortly after onset of clinical disease may nevertheless represent a regenerative effort to meet insulin demands. Compensation is, however, usually incomplete and relapse inevitably follows. If immunosuppressive treatment can halt Beta-cell destruction it is crucial that the remaining Beta cells have regenerative capacity to compensate for the losses. In view of the limited proliferative compartment of the islets it is probably necessary that such treatment is installed early in the course of autoimmune Beta cell destruction if clinically overt diabetes is not to develop. In this context it is notable that the immunosuppressant cyclosporin A inhibits islet cell replication [92] and that the effect of high-dose glucocorticoid treatment on Beta-cell growth is unknown. 
It is shown in this review that nutrients, and most notably glucose, are major stimulators of Beta-cell proliferation and that their effects can be modulated by hormones and growth factors. There is no evidence to indicate that alterations in the ability to stimulate individual Beta cells to replicate causes the development of diabetes. Available data rather suggest that limitations of the total regenerative capacity, as indicated by the size of the proliferative compartment, determine whether compensatory growth will be successful or diabetes develops. This capacity depends on pre-set genetic factors and the age of the individual. However, environmental influences may interfere with the full expression of the genetic potential. Temporary malnutrition in young rats causes a reduction of Betacell mass which persists into adult life [93]. It may thus be that early insults to Beta-cell growth and development confer a life-long reduction of the ability to increase Betacell mass and insulin production in response to diabetogenic stimuli. This notion opens new perspectives and areas of investigation.

Acknowledgements. Work by this author included in this Review was supported by the Swedish Diabetes Association, the British Diabetic Association and the Swedish Medical Research Council (12P-6947, 12P-9314, 12X-109, 12X-6538, 12X-7475).

\section{References}

1. Eisenbarth GS (1986) Type I diabetes mellitus. A chronic autoimmune disease. N Engl J Med 314: 1360-1368

2. Hellerström C (1977) Growth pattern of pancreatic islets in animals. In: Volk BW, Wellman KF (eds) The diabetic pancreas, 1 st edn. Plenum, New York, pp 61-97

3. Klöppel G, Löhr M, Hablich K, Oberholzer M, Heitz PU (1985) Islet pathology and pathogenesis of type I and type II diabetes revisited. Surv Synth Path Res 4: 110-125

4. Eriksson U, Swenne I (1982) Diabetes in pregnancy: growth of the fetal pancreatic B-cell in the rat. Biol Neonate 42: 239-248

5. Swenne I, Eriksson U (1982) Diabetes in pregnancy: islet cell proliferation in the fetal rat pancreas. Diabetologia 23:525-528

6. Borg LAH, Andersson A (1981) Long-term effects of glibenclamide on the insulin production, oxidative metabolism and quantitative ultrastructure of mouse pancreatic islets maintained in tissue culture at different glucose concentrations. Acta Diabet Lat 18:65-83

7. Swenne I (1984) The cell cycle and growth regulation of pancreatic B-cells. In: Larner J, Pohl S (eds) Methods in diabetes research. Laboratory methods, part B, Vol 1. John Wiley, New York, pp 175-191

8. De Vroede MA, In't Veld PA, Pipeleers DG (1990) Deoxyribonucleic acid synthesis in cultured adult rat pancreatic B-cells. Endocrinology 127:1510-1516

9. Swenne I (1990) Islet cell thymidine kinase activity as indicator of islet cell proliferation in rat pancreas. Diabetes 39: 70-75

10. Hellerström C, Swenne I (1985) Growth pattern of pancreatic islets in animals. In: Volk BW, Arquilla ER (eds) The diabetic pancreas, 2nd edn. Plenum, New York, pp 53-79

11. King DL, Chick WL (1976) Pancreatic beta cell replication: effects of hexose sugars. Endocrinology 99: 1003-1009

12. Swenne I, Bone AJ, Howell SL, Hellerström C (1981) Effects of glucose and amino acids on the biosynthesis of DNA and insulin in fetal rat islets maintained in tissue culture. Diabetes 29: 686-692

13. King DL, Kitchen KC, Chick WL (1978) Pancreatic B-cell replication: relation to insulin secretion. Endocrinology 103: $1321-1327$
14. Swenne I (1982) Role of glucose in the in vitro regulation of cell cycle kinetics and proliferation in fetal pancreatic B-cells. Diabetes 31: 754-760

15. Pardee AB (1989) $G_{1}$ events and regulation of cell proliferation. Science 246: 603-608

16. Swenne I (1983) Effects of aging on the regenerative capacity of the pancreatic B-cell of the rat. Diabetes 32: 14-19

17. Swenne I (1985) Glucose-stimulated DNA replication of the islets during development of the rat fetus. Effects of nutrients, growth hormone, and triiodothyronine. Diabetes 34: 803-807

18. Swenne I, Andersson A (1984) Effect of genetic background on the capacity for islet cell replication in mice. Diabetologia 27 : 464-467

19. Swenne I, Hill DJ (1989) Growth hormone regulation of DNA replication, but not insulin production, is partly mediated by somatomedin C/insulin-like growth factor I in isolated pancreatic islets from adult rats. Diabetologia 32: 191-197

20. Asplund K (1973) Effects of intermittent glucose infusions in pregnant rats on the functional development of the foetal pancreatic B-cells. J Endocrinol 59: 285-293

21. Freinkel N, Lewis NJ, Johnson R, Swenne I, Bone AJ, Hellerström C (1984) Differential effects of age versus glycemic stimulation on the maturation of the stimulus-secretion coupling during culture of fetal rat islets. Diabetes 33: 1028-1038

22. Coleman DL (1978) Obese and diabetes: two mutant genes causing diabetes-obesity syndromes in mice. Diabetologia 14: 141148

23. Dunger A, Lucke S, Klöting I, Besch W, Hahn HJ (1989) Is the DNA synthesis of pancreatic islets influenced by the MHC and/or the genetic background? Int J Pancreatol 5: 1379-1386

24. Colle E, Guttmann RD, Seemayer TA (1981) Spontaneous diabetes mellitus syndrome in the rat. I. Association with the major histocompability complex. J Exp Med 134: 1237-1242

25. Koyima I, Baetens D, Kuwajami M, Orci L, Unger RH (1990) Compensatory capabilities of BB/Wor rats exposed to sustained hyperglycemia. Metabolism 39: 614-618

26. Nicoll CS, Mayer GL, Russel SM (1986) Structural features of prolactins and growth hormones that can be related to their biological properties. Endocrine Rev 7:169-203

27. Nielsen JH (1982) Effects of growth hormone, prolactin, and placental lactogen on insulin content and release, and deoxyribonucleic acid synthesis in cultured pancreatic islets. Endocrinology 110: 600-606

28. D'Ercole AJ, Stiles AD, Underwood LE (1984) Tissue concentrations of somatomedin $\mathrm{C}$ : further evidence for multiple sites of biosynthesis and paracrine or autocrine mechanisms of action. Proc Natl Acad Sci USA 81: 935-939

29. Romanus JA, Rabinovitch A, Rechler MM (1985) Neonatal rat islet cell cultures synthesize insulin-like growth factor I. Diabetes 34: 696-702

30. Swenne I, Hill DJ, Strain AJ, Milner RDG (1987) Growth hormone regulation of somatomedin $\mathrm{C} /$ insulin-like growth factor I production and DNA replication in fetal rat islets in tissue culture. Diabetes 36: 288-294

31. Hogg J, Wang JF, Clemmons DR, Hill DJ, Han VKM (1991) Expression, release and action of insulin-like growth factors (IGFs) and IGF binding proteins (IGFBPs) in fetal rat pancreas. Diabetologia 34 [Suppl 2]: A34 (Abstract)

32. Swenne I, Heldin C-H, Hill DJ, Hellerström C (1988) Effects of platelet-derived growth factor and somatomedin C/insulin-like growth factor $I$ on the replication of fetal rat islets of Langerhans in tissue culture. Endocrinology 122: 214-218

33. Rabinovitch A, Quigley C, Russel T, Patel Y, Mintz DH (1982) Insulin and multiplication stimulating activity (an insulin-like growth factor) stimulate islet B-cell replication in neonatal rat pancreatic monolayer cultures. Diabetes 31: 160-164

34. King GL, Kahn CR, Rechler MM, Nissley SP (1980) Direct demonstration of separate receptors for growth and metabolic activities of insulin and multiplication-stimulation activity (an insulin-like growth factor) using antibodies to the insulin receptor. J Clin Invest 66: 130-140 
35. Baxter RC (1991) Insulin-like growth factor (IGF) binding proteins: the role of serum IGFBPs in regulating IGF availability. Acta Paediatr Scand [Suppl] 372: 107-114

36. Elgin RG, Busby WH, Clemmons DR (1987) An insulin-like growth factor (IGF) binding protein enhances the biological response to IGF-I. Proc Natl Acad Sci USA 84: 3254-3258

37. Rutanen E-M, Pekonen F, Mäkinen T (1988) Soluble 34K binding protein inhibits the binding of insulin-like growth factor I to its cell receptors in human secretory phase endometrium: evidence for autocrine/paracrine regulation of growth factor action. J Clin Endocrinol Metab 66: 173-180

38. Billestrup N, Nielsen JH (1991) The stimulatory effect of growth hormone, prolactin, and placental lactogen on B-cell proliferation is not mediated by insulin-like growth factor I. Endocrinology 129: 883-888

39. Francis PJ, Southgate JL, Wilkin TJ, Bone AJ (1992) Expression of an islet regenerating (reg) gene in isolated rat islets: effects of nutrients and non-nutrient growth factors. Diabetologia 35:238242

40. Han VKM, D'Ercole AJ, Lund PK (1987) Cellular localization of somatomedin (insulin-like growth factor) messenger RNA in the human fetus. Science 236: 193-197

41. Han VKM, Hill DJ, Strain AJ et al. (1987) Identification of somatomedin/insulin-like growth factor immunoreactive cells in the human fetus. Pediatr Res 22: 245-249

42. Hansson H-A, Nilsson A, Isgaard J et al. (1988) Immunohistochemical localization of insulin-like growth factor $I$ in the adult rat. Histochemistry 89: 403-410

43. Hill DJ, Frazer A, Swenne I, Wirdnam PK, Milner RDG (1987) Somatomedin- $\mathrm{C}$ in human fetal pancreas. Cellular localization and release during culture. Diabetes 36: 465-471

44. Beck F, Samani NJ, Byme S, Morgan K, Gebhard R, Brammar WJ (1988) Histochemical localization of IGF-I and IGF-II mRNA in the rat between birth and adulthood. Development 104: $29-39$

45. Scharfmann R, Corvol M, Czernichow P (1989) Characterization of insulin-like growth factor I produced by fetal rat pancreatic islets. Diabetes 38: 686-690

46. Polak M, Scharfmann R, Ban E, Haour F, Postel-Vinay MC, Czernichow P (1990) Demonstration of lactogenic receptors in rat endocrine pancreas by quantitative autoradiography. Diabetes 39: 1045-1049

47. Brelje TC, Allaire P, Hegre O, Sorenson RL (1989) Effect of prolactin versus growth hormone on islet function and the importance of using homologous mammosomatotropic hormones. Endocrinology 125: 2392-2399

48. Pledger WJ, Stiles CD, Antoniades HN, Scher CD (1978) An ordered sequence of events is required before BALB/c-3T3 cells become committed to DNA synthesis. Proc Natl Acad Sci USA 75: 2839-2843

49. Loef EB, Wharton W, Van Wyk JJ, Pledger WJ (1982) Epidermal growth factor (EGF) and somatomedin $C$ regulate $\mathrm{G} 1$ progression in competent BALB/c-3T3 cells. Exptl Cell Res 141: 107-115

50. Welsh M, Claesson-Welsh L, Hallberg A et al. (1990) Coexpression of the platelet-derived growth factor (PDGF) B chain and the PDGF beta receptor in isolated pancreatic islets stimulates DNA synthesis. Proc Natl Acad Sci USA 87: 5807-5811

51. Chatterjee AK, Siederadski J, Schatz H (1986) Epidermal growth factor stimulates (pro)insulin biosynthesis and ${ }^{3} \mathrm{H}$-thymidine incorporation in isolated pancreatic rat islets. Horm Metab Res 18: 873-874

52. Nielsen JH (1989) Mechanisms of pancreatic B-cell growth and regeneration: studies on rat insulinoma cells. Exptl Clin Endokrinol 93: 277-285

53. Chabot J-G, Walker P, Pelletier G (1987) Demonstration of epidermal growth factor binding sites in the adult rat pancreas by light microscopic autoradiography. Pancreas 2: 653-657

54. Heldin C-H, Westermark B (1984) Growth factors: mechanism of action and relation to oncogenes. Cell 37: 9-20

55. Welsh M, Welsh N, Nilsson T et al. (1987) Stimulation of pancre- atic beta-cell replication by oncogenes. Proc Natl Acad Sci USA 85: 116-120

56. Berggren P-O, Hallberg A, Welsh N, Arkhammar P, Nilsson T, Welsh M (1989) Transfection of insulin-producing cells with a transforming c-Ha-ras oncogene stimulates phospholipase $\mathrm{C} \mathrm{ac}$ tivity. Biochem J 259: 701-707

57. Terazono K, Yamamoto H, Takasawa S et al. (1988) A novel gene activated in regenerating islets. J Biol Chem 263:2111-2114

58. Terazono K, Uchiyama A, Ide M et al. (1990) Expression of REG protein in rat regenerating islets and its co-localization with insulin in the beta cell secretory granules. Diabetologia 33: 250-252

59. Terazono K, Watanabe T, Yonemura Y (1990) A novel gene, $\mathrm{REG}$, expressed in regenerating islets. In: Okamoto $\mathrm{H}$ (ed) Molecular biology of the islets of Langerhans. Cambridge University Press, Cambridge, pp 301-313

60. Morgan LM, Flatt PR, Marks V (1988) Nutrient regulation of the enteroinsular axis and insulin secretion. Nutr Res Rev 1:79-97

61. Creutzfeldt W, Ebert R (1985) New developments in the incretin concept. Diabetologia 28: 565-573

62. Larsson L-I, Nielsen JH, Rehfeld JF (1976) Presence and physiological significance of pancreatic gastrin. Diabetologia 12: A404 (Abstract)

63. Brelje TC, Sorenson RL (1991) Role of prolactin versus growth hormone on islet B-cell proliferation in vitro: implications for pregnancy. Endocrinology 128: 45-57

64. Fischer B, Rausch U, Wollny P, Westphal H, Seitz J, Aumüller G (1990) Immunohistochemical localization of the glucocorticoid receptor in pancreatic beta-cells of the rat. Endocrinology 126 : 2635-2641

65. Billaudel B, Mathias PCF, Sutter BCJ, Malaisse WJ (1984) Inhibition by corticosterone of calcium inflow and insulin release in rat pancreatic islets. J Endocrinol 100:227-233

66. Chick WL (1973) Beta cell replication in pancreatic monolayer cultures. Effects of glucose, tolbutamide, glucocorticoid, growth hormone and glucagon. Diabetes 22: 687-693

67. Andersson A (1975) Synthesis of DNA in isolated pancreatic islets maintained in tissue culture. Endocrinology 96: 1051-1054

68. Khatim MS, Gumaa KA, Abraham AK (1986) Regulation of pancreatic cell replication: an inquiry into the controversy regarding the effects of steroid hormones. Endocrinology 119: $2455-2460$

69. Khatim MS, Gumaa KA (1987) Islet growth and function. A reappraisal of the role of progesterone and prednisolone. Biochem Pharmacol 36: 2795-2798

70. Hellerström C (1963) Effects of steroid diabetes on the pancreatic islets of guinea pigs with special reference to the $A_{1}$ cells. Acta Soc Med Upsaliensis 68: 1-16

71. Kern H, Logothetopoulos J (1970) Steroid diabetes in the guinea pig: studies on islet cell ultrastructure and regeneration. Diabetes 19: 145-154

72. Hellerström C (1963) The influence of pregnancy and lactation on the endocrine pancreas of mice. Acta Soc Med Upsaliensis 68 : $17-28$

73. Marynissen G, Aerts L, Van Assche FA (1983) The endocrine pancreas during pregnancy and lactation in the rat. J Develop Physiol 5: 373-381

74. Dunger A, Lucke S, Besch W, Hahn H-J (1989) The rat pancreatic B-cell during pregnancy and lactation. Int J Feto-Maternal Med 2: 55-61

75. Tesone M, Chazenbalk GD, Ballejos G, Charreau EH(1979) Estrogen receptors in rat pancreatic islets. J Steroid Biochem 11: 1309-1314

76. Winborn WB, Sheridan PJ, McGill HC Jr (1987) Localization of progestin receptors in the islets of Langerhans. Pancreas 2: 289-294

77. Khatim MS, Al-Mahmood HA, Gumaa KA (1984) Effects of steroid hormones on DNA synthesis and insulin production of isolated foetal rat islets in tissue culture. Med Biol 62:210-213

78. Nielsen JH, Nielsen V, Mølsted Pedersen L, Deckert T (1986) Effects of pregnancy hormones on pancreatic islets in organ culture. Acta Endocrinol 111: 336-341 
79. Green IC, Howell SL, Montague W, Taylor KW (1974) Regulation of insulin release from isolated islets of Langerhans of the rat in pregnancy: effects of dietary restriction. J Endocrinol 62: $137-143$

80. Leturque A, Ferré P, Satabin P, Kervran A, Girard J (1980) In vivo insulin resistance during pregnancy in the rat. Diabetologia 19: $521-528$

81. Sharp GWG (1979) The adenylate cyclase-cyclic AMP system in the islets of Langerhans and its role in the control of insulin release. Diabetologia 16:287-296

82. Mormeaux JL, Remacle C, Henquin JC (1989) Effects of stimulation of adenylate cyclase and protein kinase-Con cultured fetal rat B-cells. Endocrinology 125: 2636-2644

83. Swenne I (1982) Effects of cyclic AMP on DNA replication and protein biosynthesis in fetal rat islets of Langerhans maintained in tissue culture. Biosci Reports 2: 1867-1876

84. Rabinovitch A, Blondel B, Murray T, Mintz DH (1980) Cyclic adenosine- $3^{\prime}, 5^{\prime}$-monophosphate stimulates $B$-cell replication in neonatal rat pancreatic monolayer culture. J Clin Invest 66: 1065-1071

85. Sugden MC, Ashcroft SJH (1978) Effects of phosphoenolpyruvate, other glycolytic intermediates and methylxanthines on calcium uptake by a mitochondrial fraction from rat pancreatic islets. Diabetologia 15: 173-180

86. Sandler S, Welsh M, Andersson A (1983) Streptozotocin-induced impairment of islet B-cell metabolism and its prevention by a hydroxyl radical scavenger and inhibitors of poly(ADP-ribose) synthetase. Acta Pharmacol Toxicol 53: 392-400

87. Pastan IH, Johnson GS, Andersson WB (1975) Role of cyclic nucleotides in growth control. Ann Rev Biochem 44: 491-522
88. Khatim MS, Al-Mahmood HA, Gumaa KA (1984) Modulation of pancreatic islet cell replication and insulin release by glibenclamide. FEBS Letters 177: 135-137

89. Kasai M, Ikeuchi M, Kanazawa Y, Kosaka K (1982) Regulation of pancreatic B-cell replication by glucose and some other substances. Biomed Res 3: 688-692

90. Sturgess NC, Ashford MLJ, Cook DL, Hales CN (1985) The sulphonylurea receptor may be an ATP-sensitive potassium channel. Lancet II: 474-475

91. Weir GC, Leahy JL, Bonner-Weir S (1986) Experimental reduction of B-cell mass implications for the pathogenesis of diabetes. Diab Metab Rev 2: 125-161

92. Andersson A, Borg H, Hallberg A, Hellerström C, Sandler S, Schnell A (1985) Long term effects of cyclosporin A on cultured mouse pancreatic islets. Diabetologia 27:66-69

93. Swenne I, Borg LAH, Crace CJ, Schnell Landström A (1990) Persistent reduction of pancreatic B-cell mass after temporary protein-calorie malnutrition in the rat. Diabetologia 33 [Suppl]: A110 (Abstract)

Dr. I.Swenne

Department of Paediatrics

Uppsala University

Children's Hospital

S-751 85 Uppsala

Sweden 